\title{
Tumor senescence and radioresistant tumor-initiating cells (TICs): let sleeping dogs lie!
}

\author{
Gaetano Zafarana ${ }^{1}$ and Robert G Bristow*1,2 \\ See related research by Karimi-Busheri et al.: http://breast-cancer-research.com/content/12/3/R31
}

\begin{abstract}
Preclinical data from cell lines and experimental tumors support the concept that breast cancer-derived tumorinitiating cells (TICS) are relatively resistant to ionizing radiation and chemotherapy. This could be a major determinant of tumor recurrence following treatment. Increased clonogenic survival is observed in CD24-llow/ CD44 ${ }^{+} \mathrm{TICs}$ derived from mammosphere cultures and is associated with (a) reduced production of reactive oxygen species, (b) attenuated activation of $\mathrm{\gamma H} 2 \mathrm{AX}$ and CHK2-p53 DNA damage signaling pathways, (c) reduced propensity for ionizing radiation-induced apoptosis, and (d) altered DNA double-strand or DNA single-strand break repair. However, recent data have shed further light on TIC radioresistance as irradiated TICs are resistant to tumor cell senescence following DNA damage. Taken together, the cumulative data support a model in which DNA damage signaling and repair pathways are altered in TICs and lead to an altered mode of cell death with unique consequences for long-term clonogen survival. The study of TIC senescence lays the foundation for future experiments in isogenic models designed to directly test the capacity for senescence and local control (that is, not solely local regression) and spontaneous metastases following treatment in vivo. The study also supports the targeting of tumor cell senescence pathways to increase TIC clonogen kill if the targeting also maintains the therapeutic ratio.
\end{abstract}

It is nought good a slepyng hound to wake.

Troilus and Criseyde (1380), Chaucer

*Correspondence: Robert G Bristow, rob.bristow@rmp.uhn.on.ca 'Radiation Medicine Program, Princess Margaret Hospital-University Health Network and Campbell Family Cancer Research Institute-Ontario Cancer Institute, 610 University Avenue, Toronto, ON, Canada M5G 2M9

Full list of author information is available at the end of the article
In the previous issue of Breast Cancer Research, KarimiBusheri and colleagues [1] shed further light on the relative resistance in breast cancer-derived tumor-initiating cells (TICs) by interrogating DNA damage signaling and repair and the capacity for tumor cell senescence in CD24-llow $/$ CD44 $4^{+}$cells derived from MCF-7 mammospheres. Primary or adjuvant breast radiotherapy is an important component in multimodality therapy as a means to improve locoregional control and potentially improve overall survival $[2,3]$. Understanding the biology underlying the relative radiosensitivity of breast tumor clonogens is an important step in personalized medicine to effectively predict clinical response and develop novel targeted therapies.

In this context, Karimi-Busheri and colleagues [1] add to the increasing literature using established cell lines and primary tumor explants on TIC resistance as the basis of treatment failure following radiotherapy and chemotherapy treatments [4-9]. Like previous investigators, the authors show that when compared with nonTIC monolayer cultures, TIC mammosphere clonogens have a decreased production of reactive oxygen species following ionizing radiation (IR) [7] and bypass the ATM/ DNA-PKcs-dependent phosphorylation of the histone H2AX in response to IR-induced DNA double-strand breaks (DSBs) [5]. Despite the bypass of the $\gamma \mathrm{H} 2 \mathrm{AX}$ response, TICs acquire hyperphosphorylation of downstream signaling proteins such as $\mathrm{p} 53, \mathrm{RB}$, and $\mathrm{CHK} 2$, a finding initially reported in glioma TIC studies [10].

As other investigators have reported, activation of AKT and canonical WNT signaling pathways within breast cancer TIC subpopulations has resulted in increased efficiency of DNA repair [5,6]. However, an increased capacity for DSB repair is not a universal finding in all TIC subpopulations [11] and may be dependent on the cell model, culture conditions, and different DSB assays. When a number of assays were used, DSB repair in TICs was unaffected in the study by Karimi-Busheri and colleagues [1]. However, the authors observed an increased capacity for the repair of DNA single-strand breaks (SSBs) associated with an increased expression of the APE1 protein. However, we do not know whether this is 


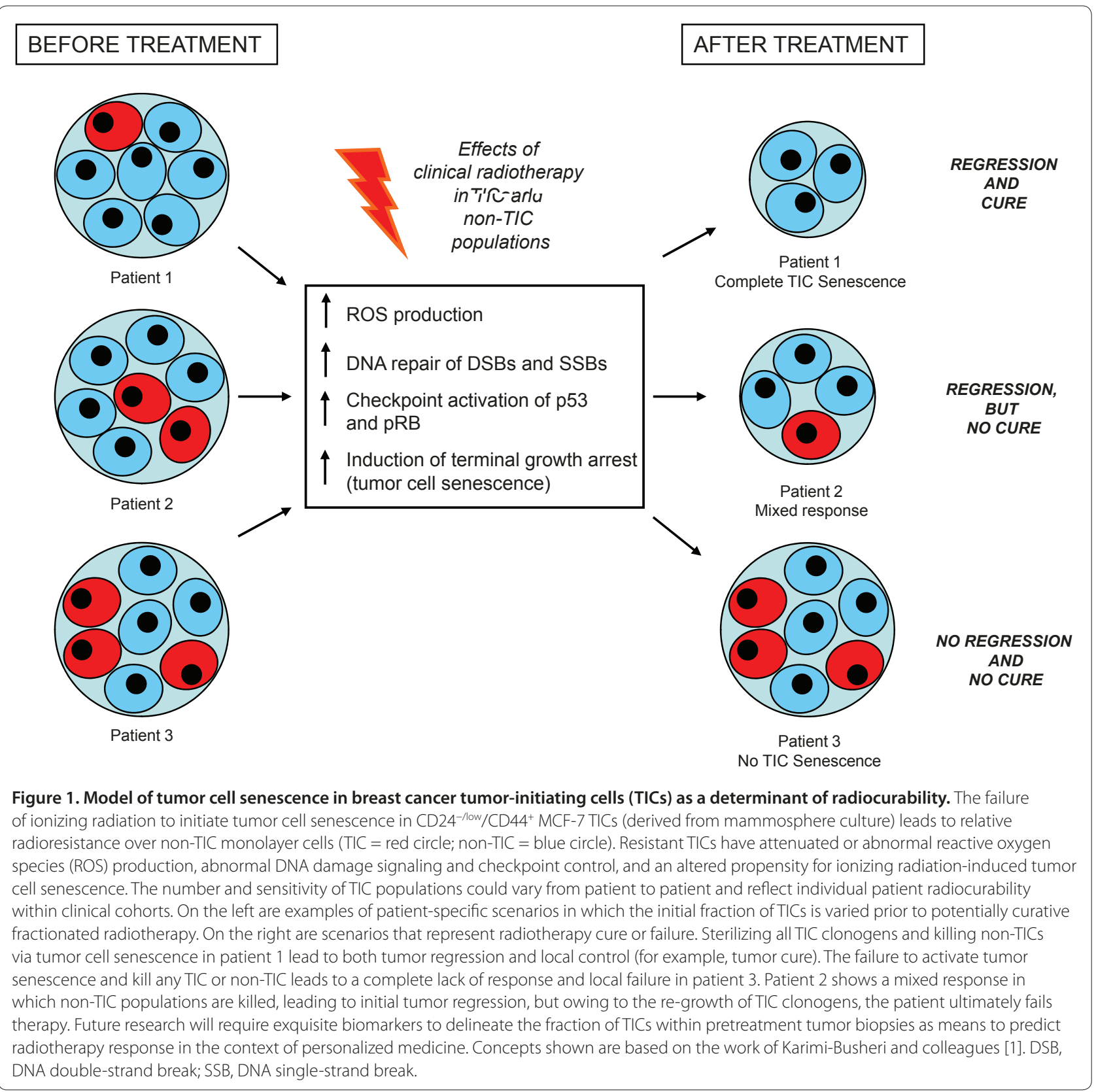

causal as SSB repair data using APE1-isogenic systems were not presented.

Where the authors truly advance the field is in their mechanistic studies of the mode of cell death in irradiated TICs versus non-TICs. Although breast cancer TICs can express high levels of antiapoptotic proteins, such as survivin or the BAX/BCL-2 family [9], the authors did not observe TIC resistance to IR-induced apoptosis. Instead, they observed that irradiated TICs have reduced tumor cell senescence associated with increased telomerase activity and increased expression of the senescence-associated proteins, including ING1, p21WAF, and SA- $\beta$ galactosidase. These results echo recent data in which fractionated IR led to a relative increase in the fraction of senescent cells in vitro in breast cancer non-TICs versus TICs [12]. The reader is left wondering how DSB repair can be normal in TICs when the ATM ${ }^{\text {ser1981 }}, \gamma \mathrm{H} 2 \mathrm{AX}$, $\mathrm{p} 53^{\mathrm{Ser15}}$, and $\mathrm{pRB}$ responses are abnormal. Future experiments therefore are required to study the upstream activation of the MRE11-RAD50-NBS1 (MRN) complexes, altered chromatin states in TICs before and after IR, and the relative control and activation of telomerase activity in TICs [5]. Nonetheless, the cumulative data support a model in which DNA damage signaling and repair pathways are altered in TICs and lead to altered modes of cell death with unique consequences for long-term clonogen survival [13]. 
However, extrapolating these data from in vitro studies directly to the relative radiocurability or chemosensitivity in vivo among individual patients in the clinic is not straightforward. If TICs are relatively resistant and determine the overall curability of a given tumor, to what extent do TIC number and radiosensitivity vary from patient to patient? Does this explain why one patient is cured and another has an initial regression only to undergo subsequent local or systemic recurrence (Figure 1)? From quantitative preclinical studies using syngeneic murine tumors or human xenografts, we know that the proportion and radiosensitivity of TICs can be measured and reflect radiocurability in vivo $[14,15]$. Yet this relationship may be further complicated by intratumor heterogeneity in which hypoxia subregions can provide a niche for TIC survival, aggressiveness, and increased metastatic capacity $[16,17]$. Indeed, it is still unclear whether local radioresistance equates directly with an increased capacity for systemic metastases $[18,19]$. At present, one cannot translate a differential capacity for DNA damage response and tumor cell senescence in TICs to a globally resistant tumor cell phenotype. But the data on TIC senescence lay the foundation for future experiments in isogenic models designed to directly test the capacity for senescence and local control (that is, not solely local regression) and spontaneous metastases following treatment in vivo [13].

The hope for personalized medicine is predicated on understanding the unique biology within and between tumors and applying this knowledge to offer the best treatment using radiotherapy, chemotherapy, or novel molecular-targeted agents [20]. Drilling down into the biology of rare TIC populations within clinical biopsies or tissues derived from solid tumors requires a level of sophistication that is currently lacking for the development and validation of single-cell TIC senescence biomarkers in vivo [9]. However, targeting tumor cell senescence pathways could increase TIC clonogen kill if this approach maintains the therapeutic ratio whereby cell kill in tumors is increased when compared with cell kill in normal tissues $[9,13,21]$. Such a strategy would drive the therapeutic concept of 'let sleeping dogs lie' or, in this case, 'die'.

\section{Abbreviations}

DSB, DNA double-strand break; IR, ionizing radiation; SSB, DNA single-strand break; TIC, tumor-initiating cell.

\section{Competing interests}

The authors declare that they have no competing interests.

\section{Author details}

'Radiation Medicine Program, Princess Margaret Hospital-University Health Network and Campbell Family Cancer Research Institute-Ontario Cancer Institute, 610 University Avenue, Toronto, ON, Canada M5G 2M9. '2Departments of Radiation Oncology and Medical Biophysics, University of Toronto, 610 University Avenue, Toronto, ON, Canada M5G 2M9.
Published: 5 July 2010

\section{References}

1. Karimi-Busheri F, Rasouli-Nia A, Mackey JR, Weinfeld M: Senescence evasion by MCF-7 human breast tumor-initiating cells. Breast Cancer Res 2010, 12:R31.

2. Bartelink $\mathrm{H}$ : Progress in radiotherapy for early breast cancer. Ann Oncol 2008, 19 Suppl 5:v117-121.

3. Moran MS, Haffty BG: Radiation techniques and toxicities for locally advanced breast cancer. Semin Radiat Oncol 2009, 19:244-255.

4. Phillips TM, McBride WH, Pajonk F: The response of CD24(-/low)/CD44+ breast cancer-initiating cells to radiation. J Nat/ Cancer Inst 2006, 98:1777-1785.

5. Woodward WA, Bristow RG: Radiosensitivity of cancer-initiating cells and normal stem cells (or what the Heisenberg uncertainly principle has to do with biology). Semin Radiat Oncol 2009, 19:87-95.

6. Zhang M, Atkinson RL, Rosen JM: Selective targeting of radiation-resistant tumor-initiating cells. Proc Natl Acad Sci U S A 2010, 107:3522-3527.

7. Diehn M, Cho RW, Lobo NA, Kalisky T, Dorie MJ, Kulp AN, Qian D, Lam JS, Ailles LE, Wong M, Joshua B, Kaplan MJ, Wapnir I, Dirbas FM, Somlo G, Garberoglio C, Paz B, Shen J, Lau SK, Quake SR, Brown JM, Weissman IL, Clarke MF: Association of reactive oxygen species levels and radioresistance in cancer stem cells. Nature 2009, 458:780-783.

8. Woodward WA, Bristow RG, Clarke MF, Coppes RP, Cristofanilli M, Duda DG, Fike JR, Hambardzumyan D, Hill RP, Jordan CT, Milas L, Pajonk F, Curran WJ, Dicker AP, Chen Y: Radiation Therapy Oncology Group translational research program stem cell symposium: incorporating stem cell hypotheses into clinical trials. Int J Radiat Oncol Biol Phys 2009, 74:1580-1591.

9. Liu S, Wicha MS: Targeting breast cancer stem cells. J Clin Oncol 2010 May 24. [Epub ahead of print].

10. Bao S, Wu Q, McLendon RE, Hao Y, Shi Q, Hjelmeland AB, Dewhirst MW, Bigner $\mathrm{DD}$, Rich JN: Glioma stem cells promote radioresistance by preferential activation of the DNA damage response. Nature 2006, 444:756-760.

11. McCord AM, Jamal M, Williams ES, Camphausen K, Tofilon PJ: CD133+ glioblastoma stem-like cells are radiosensitive with a defective DNA damage response compared with established cell lines. Clin Cancer Res 2009, 15:5145-5153.

12. Lagadec C, Vlashi E, Della Donna L, Meng Y, Dekmezian C, Kim K, Pajonk F: Survival and self-renewing capacity of breast cancer initiating cells during fractionated radiation treatment. Breast Cancer Res 2010, 12:R13.

13. Collado M, Serrano M: Senescence in tumours: evidence from mice and humans. Nat Rev Cancer 2010, 10:51-57.

14. Koch U, Krause M, Baumann M: Cancer stem cells at the crossroads of current cancer therapy failures-Radiation oncology perspective. Semin Cancer Biol 2010, 20:116-124.

15. Hill RP, Milas L: The proportion of stem cells in murine tumors. Int J Radiat Oncol Biol Phys 1989, 16:513-518.

16. Bristow RG Hill RP: Hypoxia and metabolism. Hypoxia, DNA repair and genetic instability. Nat Rev Cancer 2008, 8:180-192.

17. Hill RP, Marie-Egyptienne DT, Hedley DW: Cancer stem cells, hypoxia and metastasis. Semin Radiat Oncol 2009, 19:106-111.

18. Bristow RG, Peacock J, Jang A, Kim J, Hill RP, Benchimol S: Resistance to DNAdamaging agents is discordant from experimental metastatic capacity in $\mathrm{MEF}$ ras-transformants-expressing gain of function MTp53. Oncogene 2003, 22:2960-2966.

19. Suit H, Allam A, Allalunis-Turner J, Brock W, Girinsky T, Hill S, Hunter N, Milas L, Pearcey R, Peters L, Welch DR, West CM, Efird J: Is tumor cell radiation resistance correlated with metastatic ability? Cancer Res 1994, 54:1736-1741.

20. Hamburg M, Collins F: The path to personalized medicine. N Engl J Med 2010 Jun 15. [Epub ahead of print].

21. Roy R, Willan P, Clarke R, Farnie G: Differentiation therapy: targeting breast cancer stem cells to reduce resistance to radiotherapy and chemotherapy. Breast Cancer Res 2010, 12 Suppl 1:05.

\section{doi:10.1186/bcr2597}

Cite this article as: Zafarana G, Bristow RG: Tumor senescence and radioresistant tumor-initiating cells (TICS): let sleeping dogs lie! Breast Cancer Research 2010, 12:111. 